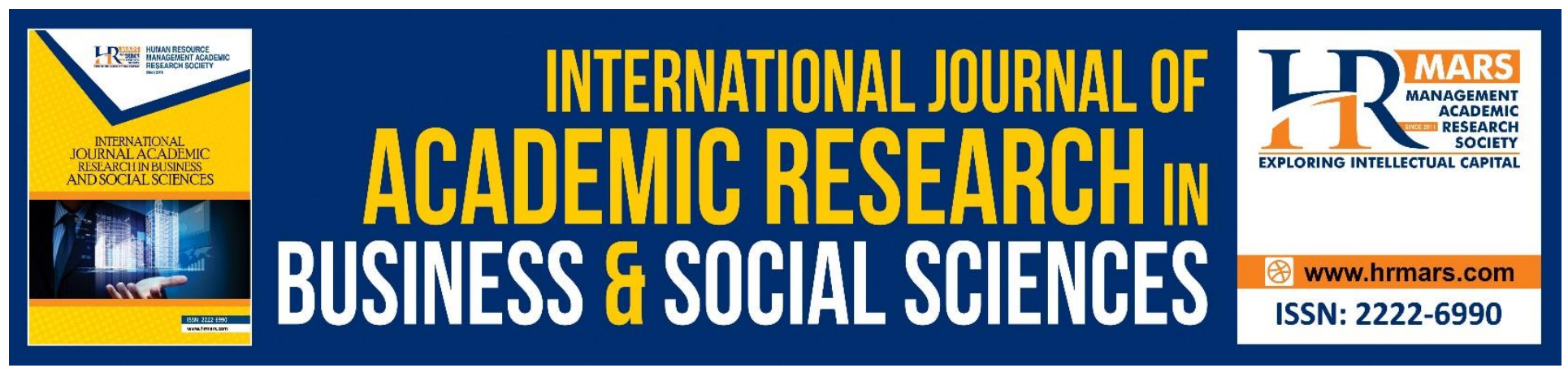

\title{
Malay Building Design Reflecting the Importance of Women in the Malay Manuscript
}

Siti Rabiatul Adawiah binti Jaffar, Arba'ie bin Sujud, Salmah Jan Noor Muhammad, Kamariah binti Kamarudin, Nadiatul Shakinah binti Abdul Rahman

To Link this Article: http://dx.doi.org/10.6007/IJARBSS/v8-i8/4620 DOI: $10.6007 /$ IJARBSS/v8-i8/4620

Received: 11 June 2018, Revised: 29 July 2018, Accepted: 30 July 2018

Published Online: 18 August 2018

In-Text Citation: (Jaffar, Sujud, Muhammad, Kamarudin, \& Rahman, 2018)

To Cite this Article: Jaffar, S. R. A. binti, Sujud, A. bin, Muhammad, S. J. N., Kamarudin, K. binti, \& Rahman, N. S. binti A. (2018). Malay Building Design Reflecting the Importance of Women in the Malay Manuscript. International Journal of Academic Research in Business and Social Sciences, 8(8), 639-646.

Copyright: (C) 2018 The Author(s)

Published by Human Resource Management Academic Research Society (www.hrmars.com)

This article is published under the Creative Commons Attribution (CC BY 4.0) license. Anyone may reproduce, distribute, translate and create derivative works of this article (for both commercial and non-commercial purposes), subject to full attribution to the original publication and authors. The full terms of this license may be seen

at: $\underline{\text { http://creativecommons.org/licences/by/4.0/legalcode }}$

Vol. 8, No. 8, August 2018, Pg. 639 - 646

http://hrmars.com/index.php/pages/detail/IJARBSS

JOURNAL HOMEPAGE

Full Terms \& Conditions of access and use can be found at http://hrmars.com/index.php/pages/detail/publication-ethics 


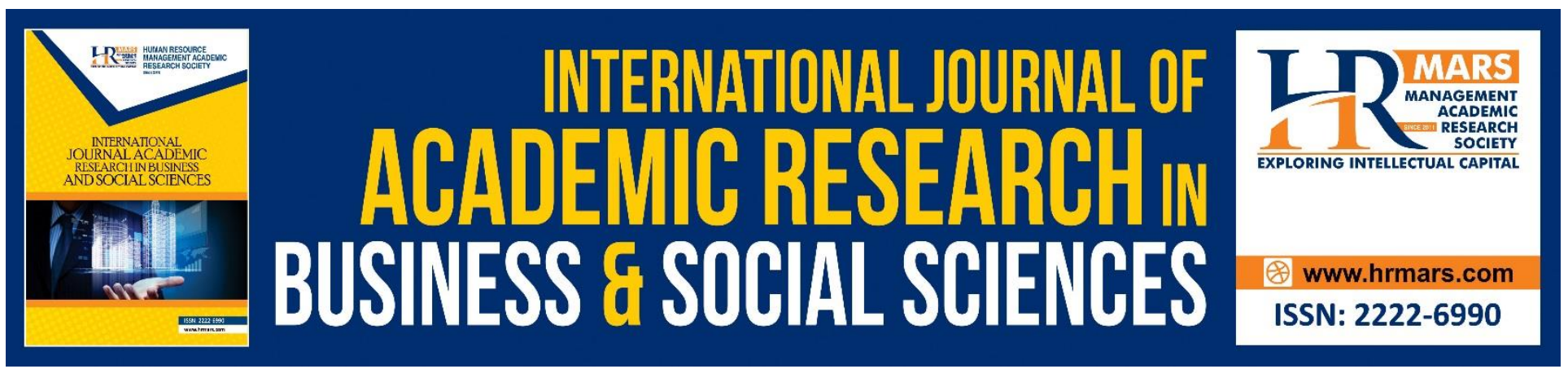

\title{
Malay Building Design Reflecting the Importance of Women in the Malay Manuscript
}

\author{
Siti Rabiatul Adawiah binti Jaffar, Arba'ie bin Sujud, Salmah Jan \\ Noor Muhammad, Kamariah binti Kamarudin, Nadiatul Shakinah \\ binti Abdul Rahman
}

Faculty of Modern Language and Communication, Universiti Putra Malaysia, Serdang Malaysia

\begin{abstract}
The design of Malay buildings that are built in diverse forms, based on three main paragraphs, which are the roof, walls and pillars are to fulfill various interests, in line with the community's lifestyle. For the Malay community, Islam has a great influence in the forming of a lifestyle, which then becomes the guide and practice of the audience. Similarly, Malay building designs, featuring designs that is related to the Islamic lifestyle. Islamic values the women's rights, as the teachings place women in a high and noble position. It is also emphasized on the creation of Malay building designs, while indirectly acknowledging the importance of women in domestic institutions. In fact, this can be examined through the Malay manuscripts, as the main source of references in examining the Malay architectural buildings and design of. Therefore, this article examines the selected Malay manuscripts in order to present the design of Malay architectural buildings, which portrays Muslim woman's lifestyle through Malik Bennabi's Cultural Theory.
\end{abstract}

Keywords: Cultural Theory, Design Of Malay Buildings, Interests, Islam, Lifestyles, Women

\section{Introduction}

The design of Malay buildings are significantly related to the lifestyle of the community. This is reflected in the architecture buildings, which are used among the public. According to Shervin (1978), the designs found, in the Malay architecture of the building, were closely related to the environment, encompassing the lifestyles of the community including beliefs and social needs. In this case, this design is associated with vernacular architecture, which is related to local elements to meet social needs and family system (Wardi \& Al-Bakri, 1979).

In relation to this, the design of the Malay buildings also features various designs that put women at the main focus, as one of the milestones of the Malay family's system of strength. The Islamic lifestyle, which is the support of the Malay community, clearly emphasizes the position of women in a social system, thus putting women in a noble order. The design of the Malay building is influenced by the lifestyle, which extends to the teachings of Islam, through its components, taking 
into account the position and importance of women in the pursuit of diverse goals (Nasir \& Teh, 1994). Furthermore, women are regarded as 'garments' to their husbands and families. This has given women full executive powers and are regarded as roles in household affairs (Hassan, 1996). In regard to this referent, the full power of women in a 'household' shows the interests of those involved in the design of the Malay building.

The Malay building design research that shows the lifestyle of women is important in ensuring the achievement of goals, through cultural outcomes that take the interest of women and then apply in the design of the building. In other words, women's confinement in the household system is an important foundation in culture, which is a measure of the design of the Malay building in meeting certain goals. In addition, narrative presentation in Malay manuscripts, can show the importance of women in Malay building designs. This is because the Malay manuscript is a written material produced with a variety of purposes and interests, used as a source of information in researching the architecture of the Malay architecture (Yahya, 1995).

\section{Methodology}

This research is a library-oriented method for analyzing Malay building designs that illustrate the importance of women in Malay manuscripts and also use Malik Bennabi's cultural theory, which focuses on the aesthetic elements, one of the four elements introduced in theory. Aesthetics or beauty flavors play an important role in the development of culture, but are the frameworks that shape civilization. The role of the appetizer is stressed as it can move the desire in further direction or beyond importance. It also adds positive values in the individual morals, which relate to the feelings and tastes of humanity. Aesthetics are also elements that give a distinctive feature to the network in society and add a picture that fits into the mood and general taste of shape and color. According to Bennabi (2003), based on social psychological aspects, the environment affects the process of thinking and behavior. Thus, a beautiful environment will have a positive effect on the mind. Vice versa. Positive effects on thinking cause positive effects to behavior.

Bennabi (2003), explains that the beauty is spread in nature and the social life born in various forms such as the colors and various methods and lives. All those beauties whether in natural or social form are well received by the community whether consciously or not, or directly or indirectly. Such beauty will then affect the behavior and shape the taste and the desire, either positive or negative. Through interaction with something beautiful and aesthetic can provide energy and creativity thus leading to diversity of behavior change and life. In fact, aesthetics in the construction of civilization are important in every aspect of life.

Beauty is seen in relation to "the atmosphere", which makes beauty a key element. About creativity relates to aesthetic elements involving feelings. In fact, individual capabilities also affect this element, involving its consideration. This aesthetic element must be approached prudently. This is because the elements are sporadic to produce models that convey the life of certain systems continuously in the pursuit (Bennabi, 2003).

\section{Analysis and Discussion}

The design of Malay buildings can be evaluated through three main components, which are the roof, column and wall (Nasir et al, 1994). In this context, the present study intends to point out three core components of the building revenue that advocate the importance of women role. 


\section{The Roof Paragraph}

The roof is the part of a building that begins with the long beam positioning up to the spine bone. Among the components found in the roof, of the roof are the throwing room or roles, attic, mansion, female rafters, rolls, mushrooms, saucer bones, jeria, sky showers, dragons, roof roofs and so on (Nasir \& The, 1994). Roof paragraphs are an important part of a building because it protects every family household from the weather and the environment. In fact, the design of the roof shows the importance of women through the mimic of the natural objects, as a symbol of the influence of local culture. Therefore, this highlights the aesthetic value of society in its identities.

“...amongst the kapa-kapa he gave him a bumbungan melintang and gajah menyusu;..."

(Sulalatus Salatin, 1979)

The design of the 'Gajah Menyusu'1 , on the roof of 'Mahligai Hawa Nafsu' is one of the most widely used roofs in the Malay peninsula, especially in Melaka (Zulkifli Hanafi, 1996). As a matter of a fact, the 'Gajah Menyusu' portrays the relationship between the Malay community and the environment, through the imitation of the natural object of the nursing elephant figure. This figure was then moved into the roof. Thus, the creation of this design explains the relationship between the Malay community and the environment and cultivate the identity of the Malay society.

The production of the elephant's roofing design is born from the artworks of the beauty of the environment, the figure of a nursing elephant. This gave rise to an influence, in terms of its aesthetic value, which later dominated the Malay community's perception and attitude, as proposed by Malik Bennabi's Cultural Theory. In this analysis, the figure of the elephant shows the role of women, providing love and protection to their children. The value affects the thinking and behavior of the community, whereby the design of the building is in proportion to the value of the natural object. The nursery elephant roof provides protection and comfort to the occupants. This has clearly exhibited in the aesthetic features of the roof of the building.

In this connection, the basic design of the roof is likely to portray the Malay community's lifestyle that focuses on the interests of women in a family institution. Women in this context, as mothers, are among the individuals suspended entirely by the child for protection and affection (Rauf \& Ibrahim, 1997). The relationship between the mother and the child is then manifested through the basic design of the roof, which explained the effects of their lifestyle that places the role of women as protector in family institution, especially when it involves mother and child relationship.

\section{The Wall Paragraph}

The wall paragraph is a building paragraph, which refers to the whole structure of the building, between the roof and the pile, including the building's living space (Mokhtar Haji Ismail \& Norazit Selat, 1992). In other words, previous research on the walls of the Malay building paragraph highlighted the body of the building, including the walls, the components of the openings, like, windows, doors and openworks and building space. Walls are the elements that are built to create spaces to the buildings and the environment. The Malay building design features a building with a multitude of additional spaces, which aims to highlight layouts based on social relationships. This is closely related to the layout of the Malay-built floor that makes social behavior and Islamic way of life as the most important element of its production (Rasdi, 2004: 33). This is reflected in the architecture of the traditional Malay castle which features buildings with various additional space

\footnotetext{
1 which is literally translated as nursing elephant
} 
INTERNATIONAL JOURNAL OF ACADEMIC RESEARCH IN BUSINESS AND SOCIAL SCIENCES

Vol. 8, No. 8, August 2018, E-ISSN: 2222-6990 @ 2018 HRMARS

with the aim of providing the leaders with the utmost in carrying out various activities throughout the day. In the traditional Malay system of governance, the role of the palace is seen as very large, including as the administrative center, where various daily activities involve government and knowledge (Mohidin, Razif \& Kadikan 2012). As such, with the added space of the cast of the palace, it allowed the king to carry out various official affairs (Harun, 2011), as explained in the text of the study:

"As in the days of Sultan Iskandar it took three seconds to three places to dwell. So early in the morning, after he prayed, he was sitting in the hall (balai lepu) and in front of all the close friends and all the slaves. So he went out on the wings (sayap) and ate it. After midday, the king was residing in the balairung faced by all the maidens and monks (kundangan). Then came the time and prayed. After performed prayer (lohor), he went out to the front hall (balai hadapan) faced by the kings and the nobles of the nobles of the people and all the trade of ministers and scholars and the poor of the people in their place. That is the greatness of the king. Then told by the person who owns the story, then it was not an abusive and persecuting person in the land of Perak ".

(Misa

Melayu, 1992)

This text excerpt illustrates the use of various spaces in the palace building as a place to carry various official government affairs. During the reign of Sultan Iskandar Zulkarnain, the palace of Indera Sakti Island was built with extra space, which resulted in the use of three different places within a day. Nevertheless, every place is inhabited by different groups or groups, whether close friends and servants, families and servants of the king then the nobles and the people.

In this case, it illustrates the social behavior based on the custom and culture of the Malay community as stated by Hilton (1956), the Malay building's built-up space was built with its cultural custom, which emphasized the privacy space to differentiate the space for members family with guests. As a symbol to the life style of the Malay community which emphasizes social behavior, this isolation also demonstrates the existence of a pattern of Islamic life, which is evidently highlight based on the separated compartments of the palace, the family and the nobles as well as the people, Mahram and non-Mahram, and between women and men (Rasdi, 2004).

Separation between women and men, who explain the patterns of Islamic life, is also noted in the architecture of traditional Malay buildings, as between claims to every Muslim family. Separation of family members (Mahram) and non-family members [non-Mahram] is focused on women as the practice of Islamic life in preserving the rank and honor of those involved. This is shown through the following passage:

"As for the king, when he has arrived in the palace, to dress and wear royal apparel.

After that, stay on top of the throne on the door of the kingdom of both husband and wives. The door was then closed for one side and open for another side. "

(Misa Melayu, 1992)

The passage illustrates the state of Sultan Iskandar Zulkarnain's throne located at the royal door. The state of the door opened on the side and closed on the other side illustrates the existence of the pattern of Islamic life in the production of his throne. The door at the throne, which functions as an open system, is also a need for privacy that separates women from non-Mahram men, thus showing the importance of honor in the life of the Muslim community.

As such, the opening system reflects the impact of beliefs that refer to the lifestyle of the Malay Muslim community. The traditional Malay building is built by considering various things, 
relating to nature, culture and religion, which all three generate towards the well-being of life. Islam basically channeled various theories of theoretical knowledge, which guided the Muslim Malays to the right. The beauty of the knowledge is then inspired to further the inspiration to art workers in developing the building that meets the demands of the knowledge involved. Thus, the appreciation of the beauty of knowledge is developed into reality and is practiced in the daily life of its society as claimed in the Cultural Theory of Malik Bennabi, through aesthetic elements.

In the meantime, the pattern of Islamic life, that places the importance of women, is emphasised in the traditional Malay society architecture. This is illustrated by the use of space as a place of custom ceremonies involving religious rituals. For example, the customs of Malay marriage, involving religious rituals such as marriage. The marriage is an important ceremony and is regarded as a starting point that confirms or permits the relationship between a man and a woman as a spouse (Jabatan Kemajuan Islam Malaysia, 2013). The ritual relationship involved with the pattern of Islamic life that is based on the importance of the family is identified through the text of the study in the passage:

"After that, then paraded into the city to the front hall (balai penghadapan). He was also facing the throne. As soon as the Raja Muda went over the hall, the hall was full of people ... After that, a betara woke up, Paduka Seri Raja Muda his title. So he stayed, upheld to his Majesty's command to Menteri Seri Paduka Tuanas for him married his son. After hearing the king's decree, he rose up in honor of his Majesty, then he read the Sayidina Ali sermon.

After marriage, the King rose up in honor of his father; he went out into the palace. "

(Misa Melayu, 1992: 21)

The excerpt explains the marriage ceremony that is held in the hall of the front hall (balai penghadapan) of Berahman Indera Palace. The frontal hall in the context of the passage lies in the front of the castle, the first space or the starting part from the front before entering the chamber of the palace. The marriage ceremony held in the space was the beginning before entering into a married life created through a marriage pronouncement. As is the position of the front hall, the first space before entering the palace, the marriage contract is also the first step or starting point that a Muslim couple must take before stepping into the realm of marriage. In this study, the frontal hall is a symbol of marriage pronouncement, while the palace is a symbol of marriage life. It is also stated in the text of the study, as described in the following passage:

"Actually, as the king said, as well as my heart, if any of the children out of Raja Muda is not worthy of being married to our children anymore. But it is a little bit of sad, since the Raja Muda had two houses (beristana dua buah), complete with him; this is what gives little barrier/ distress to my heart. "

(Misa Melayu, 1992: 12)

The quotation explains the use of traditional Malay buildings, namely 'beristana dua buah' which means already have two wives. The palace in this context is used as a figurative reference to the wife. In this case, Sultan Iskandar Zulkarnain, who was then Raja Muda, wished to embrace Raja Budak Rasul when he had two wives. For the Malay community, polygamy or married more than one wife is considered sensitive or taboo even though it is accepted as one of the forms of marriage or family form among the Muslim Malay community (Taib Othman ed., 1989). As such, in order to maintain 'facial' or 'air muka', the use of finer and more polite terms is replaced in order to ensure the validity of the message without regard to any of the parties. 
According to Ting-Toomey (1988), the traditional Malay community is well-known for its considerate attitude, which is referred as "other-concern positive faced" (Noriati A. Rashid, 2005). In this context, the use of traditional Malay buildings is related to Malay figurative speech such as proverbs, bids, and proverbs. In fact, Malay architecture is referred as a metaphor, which acts as euphemism or word sweetener, to replace the original words or phrases with softer, better, or less pronounced statement to say something that may be considered abusive or offensive (Mahali, 2007). In addition, Malay figurative language uses building to highlight the relationship between Malay architecture and women. In fact, the use of buildings, that portray wives or marriages, is often used in Malay phrases, like 'orang rumah' (someone's house), 'rumah tangga' (household) and 'nyonya rumah' (nyonya's house).

In this regard, women and architecture, whether home or palaces, are clearly associated to the beauty of the Malay community. The Malay residential buildings becomes the main place to start a family household. In fact, women have a very important role in a family, by creating a conducive atmosphere and therapeutics in married life (Hamidah binti Sulaiman, Farrah Dina Yusop \& Siti Salina Abdullah, 2007). This fact is endorsed by the Malay community and accepted as one of the social norms. Hence, this creates inspiration and appreciation that places women and homes as the same entity until the birth of a metaphor that equates women and homes. This coincides with the aesthetic elements as emphasised by Malik Bennabi's cultural theory.

\section{Conclusion}

Based on the scholarships of Malay building designs, this article presents the relationship between the Malay community's lifestyle and the Islamic teachings. The Islamic lifestyle shows that women are the pillars of the social system. The analysis and discussion show how they play a significant role in the Islamic social system, especially in family households. This interest is also applied to the design of Malay buildings, with a diverse purpose in displaying the Malays' cultural identity of the community. In other words, Islam is the basis for the life of the Malay community, is practiced and practiced as a stake that affects the lives of its people. Islam places women in the higher in order to imply the role of the group in establishing a family institution. Women are regarded as family's dignity and honour based on their establishment of their role and position. The Malay architectural buildings have clearly portrayed their roles and position in the Malay community. This indirectly shows the identity of the Malay community, which is clearly appreciated by women and families by putting two groups involved in a household priority.

\section{Corresponding Author}

Siti Rabiatul Adawiah binti Jaffar, Malay Language Department, Faculty of Modern Language and Communications, Universiti Putra Malaysia, Serdang, Selangor, Malaysia,

Email: sitirabiatuladawiah@gmail.com

\section{References}

Abdul Rauf, M. \& Che Ibrahim, M. (1997). Wanita dan keluarga dari Pandangan Islam. Kuala Lumpur: Dewan Bahasa dan Pustaka.

Ahmad, A. S. (1979). Sulalatus Salatin:(Sejarah Melayu)/diselenggarakan oleh A. Samad Ahmad. Dewan Bahasa dan Pustaka.

Bennabi, M. (2003). The question of culture. International Institute of Islamic Thought (IIIT). Bennabi, M. (2003). The Question of Ideas in the Muslim World. Islamic Book Trust. 
INTERNATIONAL JOURNAL OF ACADEMIC RESEARCH IN BUSINESS AND SOCIAL SCIENCES

Vol. 8, No. 8, August 2018, E-ISSN: 2222-6990 @ 2018 HRMARS

Haja Bava Mohidin, H. B., Mohd Razif, F. B., \& Kadikan. S.( 2012). Pengaruh Islam dalam Politik dan Seni bina Pentadbiran pada Zaman Kesultanan Melayu lama. Jurnal Teknologi (Science \& Engineering). 58: 85-88.

Hanafi, Z., Ahmad, A. G., \& Jupri, S. N. (1996). Pembinaan bangunan tradisional Melayu. AmberSolara Publication.

Harun, J. (2011). Asal-Usul Raja, Negeri dan Adat Istiadat Kesultanan Perak: Beberapa Variasi dalam Pengekalan dan Penyimpangan Sumber Tradisi. SARI, 29(1), 001.

Hassan, A. A. H. (1996). Islam dan Wanita. Jurnal Usuluddin, 4, 105-116.

Ismail, M. H., \& Selat, N. (1992). Rumah Tradisional Melayu Melaka. Persatuan Muzium Malaysia, Muzium Negara.

Ismail, M. H., \& Selat, N. (1992). Rumah Tradisional Melayu Melaka. Persatuan Muzium Malaysia, Muzium Negara.

Lip, E. (1978). An Aspect of Malaysia's Architectural Heritage'. MA. Kuala Lumpur: Malaysian Architects Association.

Mahali, S. N. H. (2007). Unsur bahasa dalam budaya. Penerbit UMS.

Malaysia. Jabatan Kemajuan Islam . (2013). Garis Panduan Upacara Akad Nikah Di Masjid Dan Perkara-Perkara Yang Berkaitan Dengannya. Perpustakaan Negara Malaysia.

Mohd Basri, A.F. (1992). Misa Melayu. Kuala Lumpur: Dewan Bahasa dan Pustaka.

Nasir, A. H., \& Teh, H. H. W. (1994). Rumah Melayu Tradisi. Fajar Bakti.

Noriati, A. R. (1990). Nilai kesantunan dalam konteks sosiobudaya masyarakat Melayu. Jurnal Pengajian Melayu, 15, 232-253.

Osman, M. T. (1989). Masyarakat Melayu: Struktur, organisasi dan manifestasi. Dewan Bahasa dan Pustaka, Kementerian Pendidikan Malaysia.

R. N Hilton. (1956). The Basic Malay House. Journal of The Malayan Branch of the Royal Asiatic Society. 29, 3 (175): 134-155

Rasdi, M., \& Tajuddin, M. (2004). Warisan seni bina dunia melayu rumah-rumah tradisional.

Shervin. M.D. (1978). The Malay House. Majalah Arkitek (1st).

Sulaiman, H. B., Yusop, F. D., \& Abdullah, S. S. (2007). Keterampilan Wanita dalam Pengurusan Rumah Tangga dan Pendidlkan Anak-Anak.

Syihab, U. (2003). Agama dan peranannya dalam pembangunan peradaban: satu kajian tentang pemikiran Malik Bennabi (1905-1973) Syihab, Usman (Doctoral dissertation, University of Malaya.).

Wardi, F \& Al-Bakri, H. (1979). "Seni Bina: Pertembungan Konsep dan Nilai Lama dan Baru”. Dewan Budaya. 1(6) : 11

Yahya, M. A. (1995). Simbolisme dalam seni bina rumah Melayu Kelantan. Dewan Bahasa dan Pustaka, Kementerian Pendidikan, Malaysia. 